\title{
The Effectiveness of Wound Book Diabetic Ulcer and Dressing on the Improvement of Modern Wound Care Knowledge in Professional Nurse Students of Universitas Muhammadiyah Purwokerto
}

\author{
Dea Alpariani', Meida Laely Ramdani ${ }^{2}$ \\ 'Student of Nursing Department, Faculty of Health Sciences, Universitas Muhammadiyah Purwokerto \\ ${ }^{2}$ Lecturer of Nursing Department, Faculty of Health Sciences, Universitas Muhammadiyah Purwokerto
}

\begin{tabular}{l} 
ARTICLE INFO \\
\hline Article history: \\
DOI: \\
10.30595/pshms.v2i.248
\end{tabular}

Submitted:

December 6, 2021

Accepted:

January 21, 2022

Published:

January 26, 2022

\section{Keywords:}

Wound Book; Diabetic Wound; Knowledge

\begin{abstract}
Wound care has developed very rapidly, especially in the last two decades which has been supported by advance health technology. In addition, the current issue of wound care management is related to changes in patient profiles which are increasingly accompanied by degenerative disease conditions and metabolic disorders. These conditions usually require proper treatment so that the healing process can be optimal, such as diabetes mellitus wounds. Based on these problems, innovation is needed that can help students learn about modern wound dressing in a book entitled wound book. It is an innovation in the form of a book to learn about proper and correct diabetic wound management and therapies that can accelerate the healing process of diabetic wounds with modern dressings. This study aimed to analyze the effectiveness of diabetic ulcers and dressings on the improvement of modern wound care knowledge in nurse students at Universitas Muhammadiyah Purwokerto. This was quantitative research that employed a one-group pretest-posttest design. The test was carried out to determine the improvement of knowledge before and after the study. The data were analyzed using the paired-sample t- test formula, in which it involved 30 nurse student. The result of the expert test showed that both media and material were in a very appropriate category. Moreover, the average scores were 4,64 and 4.60, respectively. The result above indicated that the average value of respondents' knowledge before and after being given a wound book media was 65.0012 .03 and 88.17 7,007, respectively. Meanwhile, the results of bivariate analysis using the paired-sample t-test revealed that the significance value was 0.000 (p-value 0.005 ).
\end{abstract}

This work is licensed under a Creative Commons Attribution 4.0 International License.

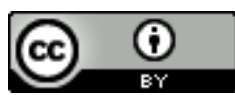

Corresponding Author:

Meida Laely Ramdani,

Department of Health,Universitas Muhammadiyah Purwokerto,

Soepardjo Rustam Street KM. 7, Banyumas, Indonesia

Email: meidalaelyramdani@ump.ac.id

\section{INTRODUCTION}

Wound care has developed very rapidly, especially in the last two decades, supported by advances in health technology. In addition, the current issue of wound care management is related to changes in patient profiles, which are increasingly accompanied by degenerative disease conditions and metabolic disorders. These conditions usually require proper treatment so that the healing process can be optimal, such as diabetes mellitus wounds. [1]

Diabetes mellitus is one of the main threats to humankind in the 21 st century. The WHO estimates that in 2000 the number of people with DM over the age of 20 years amounted to 150 million people, and within 25 years, in 2025, that number will increase to 300 million people. Cause pathophysiological changes 
in various organ systems such as eyes, kidneys, lower extremities. Diabetic ulcers are caused by three factors which are often called the triad, namely: ischemia, neuropathy, and infection. [2]

Modern Wound dressing is a wound care technique that has begun to be widely used in the $21 \mathrm{st}$ century, emphasizing the moist principle so that the wound tissue has the opportunity to proliferate and perform the cell repair cycle properly. Concluding from its history, starting from research that three world researchers have carried out since 1940 - 1970 and it was supposed that the wound care technique with a moist technique has many advantages including 1) The rate of epithelialization in wounds covered by polyethylene two times heal faster than wounds that are left dry, 2) Moist wound care does not increase infection (only $2.5 \%$ ) compared to dry treatment methods (9\%).

The use of media aims to maximize the senses in capturing messages. Media grouping based on technological developments is divided into print, audio-visual, and computer media. Health education media does not only function as a complement but can also attract attention. Media grouping based on technological developments is divided into print, audio-visual, and computer media. The acquisition of knowledge given through the sense of sight is $75 \%$ to $87 \%$, through the sense of hearing is $13 \%$ and $12 \%$ from the other reasons. The more reasons involved in capturing the message, the easier the message can be received by the target. [3]

This study will discuss modern wound dressing, a modern wound care technique that focuses on the moist principle of diabetic wounds. Modern dressings with the wet concept have many variations, so knowledge of current dressing products and skills in their application is indispensable in wound care practice. Nurses must have the ability and expertise in dressings, topical therapy, and wound care product innovation so that nurses can use them appropriately and can support the wound healing process. [3] In addition, nursing students must also have knowledge and skills in modern wound dressing care.

Based on a preliminary study conducted by researchers on ten nursing students at the University of Muhammadiyah Purwokerto on December 11, 2020, using an interview questionnaire, there were $30 \%$ who understood the treatment of diabetic ulcers with modern wound dressings, $70 \%$ did not understand the treatment of diabetic ulcers with modern wound dressings.

Based on these problems, innovation is needed to help students learn about modern wound care dressings in a book entitled "WOUND BOOK," which is an innovation in the form of a book to learn about proper and correct diabetic wound management, therapies that can accelerate wound healing-diabetes and diabetic wound care with modern dressings. Researchers chose books as a source of student learning to make it easier to understand the material. Besides being easy to carry everywhere, the wound book was designed attractively so that students felt interested in reading.

\section{METHOD}

The type of research used research using quantitative methods. The research desig nused was a onegroup pretest-posttest design. The test was conducted to determine the increase in knowledge before and after the study using the paired-sample t-test test formula. The number of respondents was 30 student nurses in Universitas Muhammadiyah Purwokerto, worked this research in June 2021.

\section{RESULTS AND DISCUSSIONS}

\subsection{Product Design}

This book is called the Wound Book, which comes from the word wound, which means wound in English, and Book means book. Wound Book is a book that explains modern dressings that are widely used in hospitals today. This book discusses the treatment of diabetic wounds using modern wound dressings. The advantage of this book with other current dressing wound care books is that it is designed attractively to give students pleasure to be interested in seeing the book and reading it. The reader can directly hold the material from the modern dressing. The benefits of this book are that the reader can find out the proper and correct management of diabetic wounds. These therapies can accelerate the healing of diabetic wounds by using modern dressings. This book also discusses Modern wound dressing, a closed and moist wound care method focused on keeping the damage from dehydration and improving the wound healing process. 


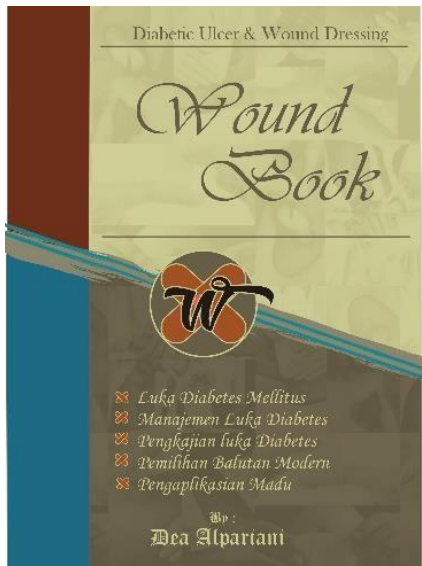

Figure 3.1 Product Validity Wound Book cover

The Wound Book that has been assessed and validated turns out to have several shortcomings that need to be revised. The input from the experts was analyzed by the researcher and then made improvements taking into account the recommendations and suggestions from the experts. The revised results of the expert assessment are summarized in table 3.1 .

Table 3.1 Summary of the results of the revised expert test assessment of the validity

\begin{tabular}{|c|c|c|}
\hline No & Before & After \\
\hline 1 & $\begin{array}{l}\text { Media Expert } \\
\text { No revisions, just suggestions to } \\
\text { smooth out the left and proper } \\
\text { alignment and added some pictures } \\
\text { for examples }\end{array}$ & $\begin{array}{l}\text { There are no revisions, and the } \\
\text { Wound Book is worthy of research }\end{array}$ \\
\hline 2 & \begin{tabular}{ll}
\multicolumn{2}{l}{ Material Expert } \\
$-\quad$ & Add diabetic \\
woundassessment \\
reference \\
$-\quad$ For Englishitalicized \\
$-\quad \begin{array}{l}\text { Types of debridement } \\
\text { explained andexamples }\end{array}$
\end{tabular} & $\begin{array}{l}\text { There are no revisions, and the } \\
\text { Wound } \\
\text { Book is worthy of research. }\end{array}$ \\
\hline
\end{tabular}

The Wound Book feasibility test uses media and material assessment instruments. The media instrument is an assessment against the Wound Book, which contains diabetic ulcers and modern dressings used. The results of the Wound Book feasibility test by media experts' feasibility validation test results with an average score of 4.60 in the "very feasible" category. The average score from material experts is 4.64 in the "very feasible" category.

\subsection{Characteristics of Respondents}

Frequency distribution of characteristics of age, gender, GPA.

Table 3.2 Frequency Distribution of Age, Gender, and GPA Characteristics. $(n=30)$

\begin{tabular}{lcc}
\hline \multicolumn{1}{c}{ Characteristics } & $\begin{array}{c}\text { Frequency } \\
(\mathrm{N})\end{array}$ & $\begin{array}{c}\text { Percentage( } \\
\%)\end{array}$ \\
\hline Gender & & \\
Male & 5 & $16,7 \%$ \\
Female & 25 & $83,3 \%$ \\
& TOTAL & $100 \%$ \\
Age & & \\
23 years & 16 & $53,3 \%$
\end{tabular}




\begin{tabular}{lcc}
24 years & 12 & $40 \%$ \\
25 years & 2 & $6,7 \%$ \\
& TOTAL & $100 \%$ \\
GPA & & \\
$3,00-3,59$ & 19 & $63,3 \%$ \\
$3,60-4,00$ & 11 & $36,7 \%$ \\
& TOTAL & $100 \%$ \\
\hline
\end{tabular}

Based on table 3.2 it is known that most of the respondents were primarily women, as many as 25 respondents $(83.3 \%)$, while only five respondents (16.7\%) were male. Based on the age characteristics of all respondents are in the adult stage (23-24 years) respondents aged 23 years as many as 16 respondents $(53.3 \%)$ respondents are aged 24 years as many as $12(40 \%)$ respondents aged 25 years $(6.7 \%)$. Based on the characteristics seen from the respondent's GPA, all respondents have a GPA value > 3.00 GPA value (3.00 $3.59)$ as many as 19 respondents $(63.3 \%)$ while respondents who get a GPA value $(3.60-4.00)$ as many as 11 respondents $(36.7 \%)$.

3.3 Knowledge Before Giving Wound Books to Nurse Students at Muhammadiyah University of Purwokerto.

Table 3.3 Knowledge Before Giving Wound Book

\begin{tabular}{|c|c|c|c|c|}
\hline Frequency (n) & Mean & Std. deviation & Min & Max \\
\hline \multirow[t]{2}{*}{30} & 65.0000 & 12.03443 & 45 & 9 \\
\hline & & & & 0 \\
\hline Knowledge & & Frequency & Perce & \\
\hline Good & & 4 & 13,3 & \\
\hline Enough & & 17 & 56,7 & \\
\hline Less & & 9 & 30 & \\
\hline
\end{tabular}

Based on table 3.3, it is known that the level of knowledge before being given a wound book media wasameanof65.0000withafrequencyof30.Basedonthetableabove, itisknownthatknowledgebefore being given wound book media got the highest score on sufficient knowledge, namely getting a score of 56 - 76 as many as 17 people $(56.7 \%)$, an average score on less knowledge, namely getting a score of $<56$ as many as nine people $(30 \%)$, and the lowest score on good knowledge is those who get a score of 76-100 as many as four people $(13,3 \%)$.

3.4 Knowledge after being given a Wound Book for Nursing Student Nurses, Muhammadiyah University of Purwokerto.

Table 3.4 knowledge after being given a Wound Book

\begin{tabular}{llccc}
\hline Frekuensi $(\mathrm{n})$ & Mean & Std.deviation & Min & Max \\
\hline 30 & 88.1667 & 7.00780 & 75 & 100 \\
\hline Knowledge & & Frequency & Precentage & \\
\hline Good & & $93,3 \%$ & \\
\hline Enough & 28 & $6,7 \%$ & \\
\hline Less & 2 & $0 \%$ \\
\hline
\end{tabular}

Based on table 4.6, it is known that knowledge after being given a wound book media is a mean of 88.1667 with a frequency of 30 . Based on the table above, it is known that knowledge after being given a wound book media obtained the highest score on sound knowledge, namely getting a score of $76-100$ as many as 28 people $(93.3 \%)$ while the lowest score on sufficient knowledge was getting a score of $56-76$ only two people ( $6.7 \%$ )

3.5 The Effectiveness of Giving Wound Book Modern Dressing to Nurse Students at Muhammadiyah 
University of Purwokerto.

Table 3.5 The Effect of Giving a Wound Book

\begin{tabular}{lccccc}
\hline Terapi & $\mathrm{n}$ & Min-max & Mean \pm SD & $\mathrm{t}$ & P-value \\
\hline Pre-test & 30 & $45-90$ & 65.0000 & \pm & \\
& & & 12.03443 & -14.329 & 0.000 \\
\hline Post-test & 30 & $75-100$ & $88.1667 \pm 7.00780$ & & \\
\hline
\end{tabular}

Based on table 3.5 can be seen the value of sig. (2-tailed) of $0.000<0.05$, that there is a significant difference between before and after being given diabetic ulcer wound book media and modern dressing, this media affects increasing the knowledge of nursing students so that it can conclude that wound book media is effective in increasing knowledge about diabetic ulcer and modern dressing.

\section{CONCLUSION}

The effectiveness of wound book media before and after can be seen in the value of sig. (2-tailed) of $0.000<0.05$, that there is a significant difference between before and after being given a diabetic ulcer wound book and modern dressing media, the wound book media has an effect on increasing knowledge about diabetic ulcers and modern dressings, and it can conclude that the wound book This is effective for advancing understanding of diabetic ulcers and modern dressings for nursing students at the Muhammadiyah University of Purwokerto.

\section{Acknowledgements}

Thank you to Allah SWT, both parents and all comrades in arms who have helped from beginning to end.

\section{REFERENCES}

[1] Katz I, EilotK,Nevo N., "I "ll do it later": Type of motivation self-efficacy and homework procrastination. Motiv.Emot. 38:1-9, 2013.

[2] Roza, R. L., Afriant, R., \& Edward, Z., "Faktor Risiko Terjadinya Ulkus Diabetikum pada Pasien Diabetes Mellitus yang Dirawat Jalan dan Inap di RSUP Dr. M. Djamildan RSI IbnuSina Padang”, Jurnal Kesehatan Andalas, 4(1), 243-248. https://doi.org/10.25077/jka.v4i1.229, 2015.

[3] Notoadmodjo, S., “Metodologi Penelitian Kesehatan". Jakarta: RinekaCipta, 2010.

[4] Kartika, R. W. et,al., "Perawatan Luka Kronis dengan Modern Dressing. Perawatan Luka Kronis Dengan Modern Dressing, 42(7), 546-550. Journal bagian bedah jantung paru dan pembuluh darah wound care/ diabetec center. RS Gading Pluit. Jakarta. 42(7): 546-550. Retrived from: https://bit.ly/2HZ27Eu, 2015.

[5] Musta'in, WeriVeranita, Setianingsih, D. P. A., "Jurnal Keperawatan \& Kebidanan Jurnal Keperawatan \& Kebidanan”,Jurnal Keperawatan, 13(1), 213-226, 2021.

[6] Fatmadona, R., \&Oktarina, E., "Aplikasi modern wound care padaperawatanlukainfeksi di rs pemerintah kota padang". Ners Jurnal Keperawatan, 12(2),159-165.Retrieved from: http://ners.fkep.unand.ac.id/index.php/ners/article/download/147/120, 2016.

[7] . Notoadmodjo S., "Promosi Kesehatan dan Perilaku Kesehatan”.Jakarta:RinekaCipta, 2014.

[8] Rika, F., \&Elvi, O., "Aplikasi Modern Wound Care Pada Perawatan Luka Infeksi di RS Pemerintah Kota Padang. Nurse JurnalKeperawatan, 12(2), 159-165, 2016.

[9] Ilmi,Z.etal., "Characterization of alginate from sargassum duplicatum and the antioxidant effect to falginate-okra fruit extracts combination for wound healing on diabetic mice". Applied Sciences (Switzerland), 10(17).https://doi.org/10.3390/app10176082, 2020.

[10] WHO., "Global Report on Diabetes". Isbn, 978, 6-86.Retrived from : https://bit.ly/37QQh9t, 2016. 